\title{
Understanding of Gold Investment Among Muslim Professionals in Terengganu, Malaysia
}

\author{
Nadhirah Nordin \\ Universiti Sultan Zainal Abidin, Malaysia \\ Email: nadhirahnor@gmail.com \\ Rahimah Embong
}

Universiti Sultan Zainal Abidin, Malaysia

Siti Khatijah Ismail

Universiti Sultan Zainal Abidin, Malaysia

Kasimah Kamaruddin

Universiti Sultan Zainal Abidin, Malaysia

Zainun Mohamed

Universiti Sultan Zainal Abidin, Malaysia

Mohamad Ariff Awang Nawi

Universiti Malaysia Terengganu, Malaysia

Doi:10.5901/mjss.2015.v6n3p110

\section{Abstract}

Gold investment is a good alternative to maintain financial stability, especially during the global economic turn-down and uncertainties. This becomes a common phenomenon among Muslims today due to the availability of its multiple products, techniques, marketing plans in the current market. Many Muslim investors are eager to get involved in the gold investment, however, some of them do not realize about there are certain products, techniques and marketing plan which are not invalid from a legal standpoint. Therefore, this study was carried out in order to explore about the basic understanding of gold investment among Muslim professional investors. This is a field study that employed the quantitative method where data were obtained through questionnaires. The respondents comprised 300 Muslim professionals from three selected higher institutions which are located in Kuala Terengganu namely Universiti Sultan Zainal Abidin (UniSZA), Universiti Malaysia Terengganu (UMT) and Universiti Teknologi MARA (UiTM). The result of linear regression analysis indicated that, seven significant predictor variables were contributing factor to the level of knowledge about basic gold investment among Muslim professionals in Kuala Terengganu. This suggests that, nul hypothesis were rejected and it could be concluded in general, the seven predictor variables were contributing about 73.9 per cent $(r=0.859)$ changes of variance in the level of their knowledge about basic investment gold. While a total of 26.1 percent change in variance was influenced by other variables which do not contribute to this analysis.

Keywords: gold investment, understanding, Muslim professionals, financial stability

\section{Introduction}

Gold is a very special metal. Its interesting colors and the difficulty of getting it cause it is considered worthy to mankind. The specialty of gold and its importance in human life are also much mentioned in the Quran as The God the Almighty says: 
Among the People of the Book there is he who, if thou trust him with a treasure, will return it to thee; and among them there is he who, if thou trust him with a dinar, will not return it to thee, unless thou keep standing over him. That is because they say, 'We are not liable to blame in the matter of the unlearned;' and they utter a lie against Allah knowingly. (al-'Imran: 76).

In the context of this verse, the gold refers to the currency of dinar. The permissibility of making gold as a stable saving can be observed through its value mostly are still equivalent since the time of Prophet Muhammad to the present day. Meanwhile, in a hadith, Syahib bin Garqadah said:

I hear people were talking about 'Urwah, indeed the Prophet SAW gave him one dinar to buy a goat for him, then with one dinnar, he bought two goats and then he sold one for one dinar. When he came back, he brought along one dinar and one sheep. The Prophet SAW prayed for him with the blessing on his business. If Urwa bought the land, he is definitely gaining profit.

(Reported by al-Bukhari)

This hadith indicates that the price of a goat at the time of the Prophet was about a dinar. Interestingly, the stability of the gold price is clearly proven in the price of a goat today is about RM750 or one dinar (equivalent to the value of 4:25 grams gold ). It is undeniable that gold has become an essential source of wealth because it cannot be destroyed and will not decrease its value, but always increasing for a long term. The history has witnessed that that most communities and cultures consider gold has high value. Even though, nowadays gold is no longer used as the main currency, but it still becomes one of the most valuable assets.

Recently, gold investment has become one of the best alternative investments to protect individual wealth due to the issue raised regarding paper money may lose its value (Syukor, 2009). There are various forms of products and techniques gold investment that available in the current market. Yet, in the enthusiasm of the gold investment activities, many investors, including the Muslim professional gold investment are being lured into fraud cases as a result of confusion and lack of understanding about gold investment. Lately, many fraud cases done by investment companies had been reported, for instance, gold investments promoted by Geneva Malaysia Sdn. Limited company. There were about 50000 investors suffered losses when the company did not get the approval from Central Bank of Malaysia. In fact, the three directors of the company were charged in the Sessions Court for the case of accepting deposits from the public without a valid license (Star 2012 http://www.theedgemalaysia.com).

As a consequence, the $100^{\text {th }}$ Dialogue of the Fatwa Committee of the National Council for Islamic Religious Affairs, Malaysia held on $4^{\text {th }}-6^{\text {th }}$ July 2012 have debated on the ruling of such transaction and gold investment undertaken by the company. As a result of the discussion, the Council has decided that such transaction does not fully comply Gold Investment Parameters as has been recommended by the $96^{\text {th }}$ Dialogue of the Fatwa Committee of the National Council for Islamic Religious Affairs Malaysia in 13 $3^{\text {th }}-15^{\text {th }}$ October, 2011.

Such well-planned scam syndicates should be dealt immediately because it can trigger a variety of economic and social problems among victims and society. Therefore, this study is necessary to identify what are the factors in choosing gold, investment or what are the advantages of this kind investment? Does a Muslim professional make an investment based on a clear understanding or just following the current trend or lured by advertisements and promotions that promise quick returns. There are a variety of products, marketing plans and techniques of gold has caused many people are tend to get involved in gold investment. Hence, this research is vital to guide the community in general and Muslims in particular in a proper way of gold investment.

The investment has a positive impact in improving the economy among Muslims and capable of competing with non-Muslims who have already practiced this long time ago. Thus, it is very necessary to make some recommendations in order to enrich information about it and to create awareness about Shariah-compliant gold investment among Muslims.

\section{Literature Review}

There are various writings and researches on gold done by scholars. However, their focus is on the role and mechanism of the gold dinar as currency (Salmy Edawaty, 2011: Hussin \& Zanirah, 2011). The proposal of using the gold dinar was commenced by former Prime Minister of Malaysia, Tun Dr. Mahathir Mohammed in 2001. Subsequently, this issue began to be highlighted by financial experts and scholars in Malaysia. Until today, several alternatives of its use have been proposed and implemented which are the use of the gold dinar in international trade, the electronic payment system (edinar), savings, payment of tithes, gifts, investments, and a marriage dowry (Salmy Edawaty \& Hailani, 2011). Rab (2002) also emphasizes the stability of the gold dinar against the paper money. 
In a study of gold investment, Mansor (2010), Umar Azmon (2002) and Zuhaimy (2003) conclude that the saving of gold dinar as assets is a good investment compared to other investments which are not based on gold. It is due to the stability of its value and the popularity of gold investments in global markets is increased (Syed Alwi, Suhaimi \& Mohamed Kamil, 2013). Baur and Lucey (2010) prove the potential of gold as a stable asset when their findings indicate the value of gold remains stable even when the stock market declined significantly in the United States, the United Kingdom and Germany. Gold is also inflation-proof investment (Louis Ng, 2011: Hafizi et. al, 2012 ).

One of the important aspects of gold investment is in terms of its compliance with the Islamic law. Recent trends show a tendency in the Malaysian community to invest in gold as a form of Sharia-compliant investment gold (Hafizi et al., 2012). Studies done by Akhtarzaite (2012), Lokmanulhakim et.al (2012) and Burhanuddin (2012) analyze a number of products, plans and investment techniques which are available in the market based on the principles and rulings of gold investment from Islamic law. The findings of the researches have shown that most of the investment plans available in the market do not meet the basic transaction of gold, especially regarding handover of gold. It is also supported by findings from Hafizi et. al (2012), which shows that only one out of seven that offer gold savings account in Malaysia is syariah compliant.

Although there are studies on gold investment have been done, no studies done specifically to examine the level of knowledge, especially among the Muslim community. Lack of literature related to case studies on gold investment as a mechanism of investment implies strong justification on why such study should be performed. Despite the fact that gold investments are gaining momentum among investors (http://www.imoney.my/articles/pelaburan-emas-di-malaysia). Accordingly, a study focuses on gold investments among Muslim professionals is very significant, especially for the economic survival of Muslim people. The level of understanding in basic knowledge and rulings, especially among the Muslim community should be explored and studied. This information is important for the authorities to take certain steps to increase awareness and provide a clear explanation to the public at large and Muslims in particular.

\section{Research Methodology}

This study involves an analysis of data obtained from 300 questionnaires. Although the researchers initially distributed 600 questionnaires, only 300 questionnaires were returned. The data from the questionnaires were analysed using SPSS. The sample of this study consisted of 300 academic staff from three selected higher institutions which are located in Kuala Terengganu namely University of Sultan Zainal Abidin (UniSZA), Terengganu Malaysia University (UMT) and University of MARA Technology Institute (UITM). The respondents were purposely selected from academic staff consisted of tutors, lecturers and professors. They were assumed to be qualified to be called as a Muslim professional due to their high qualifications in academic background and having degree in bachelor or master or doctor of philosophy. The collection of data for this study is conducted from January until March 2013.

The content of questionnaire covers specifically the research issues. The questionnaire consists of two parts; part $A$ is the demographics of the respondents and part $B$ is a basic understanding of the respondents about gold investment. The respondents were assessed based on Five-Point Likert Scale, 1: Not important at all, 2: slightly important, 3: moderately important, 4: very important, 5: absolutely important. To analyze the data, the study employs two methods of analysis: descriptive and linear regression.

\section{Empirical Findings}

The questionnaire consists of sections A and B. Part A contains 8 questions consisting of age, gender, level of education, job, income, universities, faculty, and involvement in the gold investment. While section B contains 10 questions.

Section A: The Respondents' Profiles

Table 1: Social Demographic of the respondents

\begin{tabular}{llcc}
\hline Respondents' Profiles & Category & Frequency & Percentage \\
\hline Age & $20-30$ years old & 108 & 36.0 \\
& $31-40$ years old & 108 & 36.0 \\
& $41-50$ years old & 59 & 19.7 \\
Sex & 51 years old and above & 25 & 8.3 \\
& Male & 90 & 30.0 \\
\hline
\end{tabular}




\begin{tabular}{llcc}
\hline Level of Education & Bachelor's Degree & 54 & 18.0 \\
& Master Degree & 192 & 64.0 \\
Position & Doctor of Philosophy & 54 & 18.0 \\
& Professor & 6 & 2.0 \\
& Associate Professor & 13 & 4.3 \\
& Lecturer/ Senior Lecture & 212 & 70.7 \\
& Tutor/ Fellow/ Assistant Lecturer & 69 & 23.0 \\
& RM 2000-RM3999 & 90 & 30.0 \\
& RM4000-RM5999 & 94 & 31.3 \\
Period of Involvement in Gold Investment & RM6000-RM7999 & 49 & 16.3 \\
& RM8000 and above & 67 & 22.3 \\
& Below 5 years & 80 & 26.7 \\
& $6-10$ Years & 6 & 2.0 \\
& $11-15$ Years & 4 & 1.3 \\
& 15 Years and above & 4 & 1.3 \\
& Not involved & 206 & 68.7 \\
\hline
\end{tabular}

The age of respondents was categorized into four levels: 20 to 30 years is 108 respondents (36\%), 31 to 40 of 108 (36\%), 41 to 50 is 59 respondents (19.7\%) and 51 years and above was 25 respondents (8.3\%). The majority of respondents from a total of 210 respondents are female (70\%) and male was 90 respondents (30\%). Highest education level of the respondents was master degree is $192(64 \%)$ both Bachelor's degree and PhD were 54 respondents (18\%). A total of $212(70.7 \%)$ were the respondents comprised lecturers and senior lecturers and tutor, fellows and assistant lecturers 69 respondents (23\%), the Professor was 13 respondents (4.3\%), and Professor was 6 respondents (2\%). A total of $31.3 \%$ of respondents had income between RM4000 to RM5999, followed by $30 \%$ had income between RM 2000 to RM3999. While $22.3 \%$ had income RM8000 and over; and 16.3\% RM6000 had income RM7999. A total of $30.7 \%$ of the respondents involved in gold investment while $69.3 \%$ did not get involved with this investment. A total of 79 respondents (26.3\%) had involved in gold investment for 5 years, 2\% for 6 to 9 years, 1.0\% for 10 to 14 years and 1.3\% for 15 years.

Section B: Understanding about Gold Investment

Table 2: Understanding about Gold Investment

\begin{tabular}{lcc}
\hline Bil. Item & Min & Standard Deviation \\
\hline 1. I study the ins and outs of gold investment. & 2.71 & 1.207 \\
2. There are various brands of gold available in the market such as Kijang Emas, Rabbani Dinar, & 3.68 & 1.030 \\
Dinar Hana, Public Gold Dinar and other forms of gold. & & 1.003 \\
There is a difference in terms of purity of gold among the types of gold 999 or 916 or 917, gold & 4.02 & 0.782 \\
3. bars or coins dinars etc. & 4.52 & 0.886 \\
4. The price of gold may go up and down & 3.98 & 1.137 \\
5. The return of gold investment is high. & 3.80 & 0.848 \\
6. I will start investing after getting a clear formation about it. & 4.27 & 0.933 \\
7. Gold investment is a long-term mechanism of savings & 3.88 \\
8. There are several types of optional form of gold investment, such as the purchase of physical gold & 0.863 \\
and gold savings accounts. & 4.13 & 0.969 \\
9. Physical gold consists of gold bars, gold coins and jewelry. & 3.85 & \\
10. Not all forms of gold investment practiced are Shariah compliant. & \\
Alpha Cronbach = 0.845 & \\
Number of Item $=10$ & \\
Number $\mathrm{N}=300$ & & \\
\hline
\end{tabular}

Reliability of instruments is very important for maintaining the accuracy of the instrument exposed to the defect. The higher the value of the Cronbach Alpha coefficients and the level of the validity and reliability of the instrument, the more accurate the data will be obtained in order to produce a good quality research. Based on table 2, the Cronbach Alpha coefficients generated was 0.845 and it is acceptable as a tool of measurement as mentioned by Sekaran (2003). 
Table 3: Linear Regression Analysis for Level of Knowledge about Basic Gold Investment

\begin{tabular}{lcccc}
\hline Predictor variables & B & Standard Deviation & Beta $(\boldsymbol{\beta})$ & $\boldsymbol{p}$-value \\
\hline Various Brands of Gold & 0.064 & 0.021 & 0.126 & 0.002 \\
Different originality of gold & 0.102 & 0.019 & 0.194 & 0.000 \\
The Fluctuation of gold price & 0.049 & 0.023 & 0.073 & 0.034 \\
Higher returns of Gl & 0.098 & 0.022 & 0.165 & 0.000 \\
Starting GI After Getting Information & 0.070 & 0.018 & 0.151 & 0.000 \\
Mechanism of Long-Term Savings & 0.027 & 0.026 & 0.044 & 0.299 \\
There are Several Types of Choices in GI & 0.028 & 0.023 & 0.049 & 0.240 \\
Physical gold Made From Gold Bars, Gold Coins and Jewelry & 0.140 & 0.029 & 0.229 & 0.000 \\
Not all Shariah-compliant & 0.034 & 0.019 & 0.062 & 0.077 \\
Studying the intricacies of GI & 0.088 & 0.016 & 0.201 & 0.000 \\
$\mathrm{R}=0.859$ & & & & \\
$\mathrm{R}^{2}=0.739$ & & & &
\end{tabular}

Hypothesis Nul = No significant predictor variables the level of knowledge about the basics of investing in gold among the Muslim professional as in Kuala Terengganu. Alternative hypothesis = There is at least one significant predictor variable in the basic knowledge of gold investments among Muslim professionals in Kuala Terengganu. The result of data had been analyzed using linear regression analysis for the level of knowledge about the basics of gold investment shows there are seven significant predictor variables, namely:

Studying the intricacies of $\mathrm{GI}(\beta=0.201, p<0.05)$

Various brands of gold $(\beta=0.126, p<0.05)$

Different Purity of Gold $(\beta=0.194, p<0.05)$

Fluctuation of gold price $(\beta=0.073, p<0.05)$

Higher Return of $\mathrm{Gl}(\beta=0.165, p<0.05)$

Start $\mathrm{Gl}$ after getting information $(\beta=0.151, p<0.05)$

Physical Gold consists of Gold Bars, gold coins and jewelry $(\beta=0.229, p<0.05)$

The seven variables above were contributing factor to the level of knowledge about basic gold investment among Muslim professionals in Kuala Terengganu. Therefore, nul hypothesis were rejected and it could be concluded in general, the seven predictor variables were contributing about 73.9 per cent $(r=0.859)$ changes of variance in the level of their knowledge about basic investment gold. While a total of 26.1 percent change in variance was influenced by other variables which do not contribute to this analysis.

\section{Concluding Remarks}

Investment is the action of placing funds for a certain period to earn the rate of return required, with fully aware of the risks involved (Rosli, 1997). Generally, investments made to gain profit. In order to begin an investment, an individual needs certain funds and capital, whether in form of currencies, real estate, gold, stocks and so on. As such, investors have a wide choice of investment instruments such as investing in gold, real estate, trust and many others. However, there is a tendency among investors to choose gold investment compared to other forms of investment.

Gold investment is a smart alternative to maintain financial stability, especially during the great depression. This has become a phenomenon among Muslims today with the existence of various forms of products, techniques and investment plans of gold in the current market. However, in the passion of Muslim investors to invest in gold investment, there are products, techniques and investment plans of gold not permissible legally.

This study was conducted to find out how far Muslim among professional investors having the understanding about gold investment. The results of the research showed the level of knowledge of respondents in the understanding of investment gold is moderate because they were lacking in reviewing about the information and issues pertaining gold investment and were less exposed to the information about gold investment either through mass media or electronic media. 


\section{Acknowledgements}

The authors acknowledge the financial support from Universiti Sultan Zainal Abidin, Malaysia for this academic research (Project Number: UniSZA/13/GU 008).

\section{References}

Akhtarzaite, A. A. (2012). Emas dan Pelaburan Daripada Perspektif Syariah [Gold and investments from the perspective of Shariah]. Paper presented at $8^{\text {th }}$ Discourse among members of the Shariah Advisory Council of the Financial Institutions in Malaysia, Putrajaya International Convention Center, 29th May.

Babbie, E. (2010). The Practice of Social Research.USA: Wadsworth Cengage Learning

Baur, D.G., \& Lucey, B.M. (2010). Is gold a hedge or a safe haven? An analysis of stocks, bonds and gold. The Financial Review.

Burhanuddin, L. (2012). Produk Pelaburan Emas di Malaysia: Satu kajian mengikut perspektif Figh Islam [Gold investment products in Malaysia: a study based on the perspective of Islamic jurisprudence]. Paper presented at $8^{\text {th }}$ Discourse among members of the Shariah Advisory Council of the Financial Institutions in Malaysia, Putrajaya International Convention Center, $29^{\text {th }}$ May.

Chua, Y. P. (2006). Kaedah dan Statistik Penyelidikan [Research methods and Statistics].Kuala Lumpur: McGraw-Hill Education

Hafizi, A.M., Noreha, H., Norzalita, A. A. \& Hawati, J. (2012), Gold Investment in Malaysia:Its Operation, Contemporary Applications and Shariah Issues. Paper presented at the Conference on Malaysian Islamic Economics and Finance 2012, 5 - 6 November 2012, Bangi.

Hussin, S. \& Zanirah, M. (2009). Pelaksanaan Dinar dalam Sistem Ekonomi Moden: Cabaran dan Prospek Masa Depan [Implementation of Dinars in Modern Economic Systems: challenges and future prospects]. Paper presented at International Seminar on Generating Economics through Transactions of Dinar Currencies 2009: Dinars as an Alternative Today and Future. Pp. 131-148.

Lokmanulhakim, H. et.al (2012). Analisis Syariah terhadap produk-produk pelaburan emas di Malaysia [Sharia analysis of gold investment products in Malaysia]. Paper presented at $8^{\text {th }}$ Discourse among members of the Shariah Advisory Council of the Financial Institutions in Malaysia, Putrajaya International Convention Center, 29th May.

Mansor, H. I. (2012) "Financial market risk and gold investment in an emerging market: the case of Malaysia", International Journal of Islamic and Middle Eastern Finance and Management, Vol. 5 Iss: 1, pp.25 - 34. 5 (1): 25 - 34

Mohd Najib, A. G. (2003). Reka Bentuk Tinjauan Soal Selidik Pendidikan [The Design of the Survey Questionnaire of Education]. Skudai: PenerbitUniversitiTeknologi Malaysia

Rab, H. (2002). Problems Created by the Fiat Money, Islamic Dinar and Other Available Alternatives. Paper presented at the 2002 International Conference on Stable and Just Monetary System: Viability of the Islamic Dinar, 19 - 20 August, 2002, International Islamic University Malaysia, Kuala Lumpur, Malaysia.

Rosli, M. (1997), Konsep Asas Pelaburan [Basic Concepts Of Investment]. Kuala Lumpur: Dewan Bahasa dan Pustaka.

Salmy, E. \& Hailani M.T. (2009). Realiti penggunaan dinar emas di Malaysia [The reality about the use of dinar in Malaysia]. Paper presented at International Seminar on Generating Economics through Transactions of Dinar Currency 2009: Dinars as an Alternative Today and Future. Bangi, 27 August, pp. 347-360.

Salmy, E. (2009). Realiti semasa penggunaan dinar emas di Malaysia [The current reality of dinar in Malaysia]. Kuala Lumpur: Utusan Publications and Distributers Sdn. Bhd.

Sekaran, U., (2003), Research method for business: A skill building approach, 4th ed. New York: John Willey \& Sons.

Syed Alwi, S. \& Mohamed K. (2013),Gold Investment Account in Kuwait Finance House (M) Berhad and Maybank Berhad, Global Journal Al-Thaqafah, Vol. 3 Iss: 1, pp.31-39.

Syukor, H. (2009). Bagaimana membuat pelaburan emas di Malaysia [How to make gold investment in Malaysia]. Paper presented at International Seminar on Generating Economics through Transactions of Dinar Currency 2009: Dinars as an Alternative Today and Future. Bangi, 27 August.

The Star. (2012). Gold investment. [Online] Available: http://www.theedgemalaysia.com (Dec 25, 2013)

Umar Azmon, A. H. (2002). Penggunaan mata wang dinar dalam era globalisasi [the use of dinar currency in the era of globalization] . A paper presented at National Seminar on Dinar. Kuala Lumpur, 16 March.

Unknown, Pelaburan emas di Malaysia [Gold investment in Malaysia] [Online] Available: http://www.imoney.my. (Dec 28, 2013)

Utusan Malaysia (2012). 2 October.

Zuhaimy, I. (2003). Kembalinya Dinar Emas dan Dirham [The Return of Dinar and Dirham]. Perak. Johor: UTM Skudai. 